\title{
КУЛТУРА НАРОДА НАСИ КРОЗ ПРИЗМУ НА-СИ СРПСКОГ РЕЧНИКА ДРАГАНА ЈАНЕКОВИЋА
}

\section{Сажетак}

Народ Наси (познат и под називима Нахи, Нари, Моша, Моси, Лоло, Донгба, „Монголи југа“), једна су од 56 етничких мањина у Кини. Има их око 300.000 и настањени су углавном у древном граду Лиђианг - провинција Јунан.

Филозофија живота народа Наси почива на Донгба религији, названој према шаманима и мудрацима тзв. Донгбама, главним преносиоцима и чуварима традиције, културе, језика и писма. Старе Донгбе су своје религиозне сутре писали пиктографским писмом које данас, на читавом свету, уме читати једва неколицина људи.

Привучен лепотом Донгба културе, која се 2003. године нашла на листи светске културне баштине, српски дипломата Драган Јанековић је 2005. године објавио Наси српски речник са 1803 пиктограма о језику, култури, обичајима, веровањима, традицији и свакодневном животу народа Наси.

Осим пиктограма са значењима и изговором прилагођеним српској фонетици, На-си српски речник садржи упутства за читање Донгба рукописа, преводе три античка Донгба рукописа на српски језик и српску поему „Смрт мајке Југовића“ препевану на Донгба хијероглифе.

Тумачећи магичне пиктограме На-си српског речника, од поједи-начних слика креираћемо велелепни мозаик ове надасве занимљиве и аутентичне древне културе.

Кључне речи: На-си српски речник, Драган Јанековић, Наси, Донгба култура, етничка мањина, Кина, Лиђианг, језик, пиктографско писмо, хијероглифи, Смрт мајке Југовића

\author{
Увод \\ На народ Наси пажњу света скренула су два истраживача - \\ аустријско-амерички лингвиста и ботаничар Џозеф Рок (Joseph F.
}


Rock, 1884-1962) и руски писац и таоистички лекар Питер Гуларт (Peter Goullart, 1901-1975), који су живели у Лиђиангу и путовали широм подручја почетком 20. века. Књига Питера Гуларта Заборављено краљевство (Forgotten Kingdom, 1957) описује живот и веровања народа Наси и суседних народа, док заоставштина Џозефа Рока обухвата дневнике, мапе и фотографије из региона. Роков Наси-енглески енциклопедијски речник (А ${ }^{1} \mathrm{Na}-{ }^{2} \mathrm{Khi}-\mathrm{English}$ encyclopedic dictionary, 1963) објављен је постхумно у Институту за оријенталистику у Риму. Књиге и значајне радове о Наси култури оставили су бројни кинески научници: Taо Yunkui, Bai Gengsheng, Yang Fuquan, Guo Dalie и др.. У научном опусу о Донгба култури посебно место заузимају речници: Ланканов (Li Lincan) Речник Мо-со хијероглисра (Dictionary of Mo-so hieroglyphics, 1953), Речник Наси пиктограма (A Dictionary of Naxi pictographic characters, 1995) који су приредили Fang Guoyu и Hе Zhiwu и Ли Говенов (Li Guowen) Речник Донгба културе (Dictionary culture Dongba, 1997).

Лепота Донгба културе привукла је и српског дипломату Драгана Јанековића ${ }^{1}$, који 2005. године уз помоћ Народне библиотеке Србије објављује јединствени Наси-српски речник, са 1803 пиктограма о језику, култури, и свакодневном животу народа Наси.

Наси-српски речник нас од самог почетка уводи у чаробан свет Насија. Речник се састоји из три дела. Први део садржи Наси пиктограме са изговором прилагођеним српској фонетици и значењима на српском језику. Следе упутства за читање Донгба рукописа са примерима за њихово тумачење. У другом делу речника, на српски језик су препеване три древне приче из колекције Донгба античких књига: „Сеобе људи“, „љубавна прича“ и „Рат црног и белог“. Читајући ове приче упознајемо основне религиозне идеје, брачне везе и историјски

1 Драган Јанековић (Београд, 1960), правник, дипломата у Министарству спољних послова СЦГ. До 2002. године био је конзул у Генералном конзулату СЦг у Шангају и Кини. Током боравка у Кини, обишао је многе провинције и градове и научио кинески језик и писмо. У провинцији Јунан боравио је неколико година као истраживач и преводилац. Савладао је Донгба сликовно писмо и превео га на српски језик, сврставши се тако међу неколицином људи у свету који данас разумеју ово мртво писмо и изумирући језик народа Наси. Од 2002. године налази се у дипломатској мисији у Мјанмарској унији. Након Наси-српског речника, „Моно и Мањана“ издају 2010. године његову другу књигу Дамапада, књигу Будиних изрека, преведену са Палија, за коју је користио бурмански алфабет и начин изговора Палија. 
развој народа Наси. Трећи део речника чини препев српске поеме „Смрт мајке Југовића“ на донгба хијероглифе.

Јанековићев речник је први свеобухватни и систематски речник намењен читаоцима неенглеског говорног подручја. Посебна вредност књиге огледа се у чињеници да је у време њеног настанка, на прагу 21. века, Јанековић за све недоумице консултовао Yang Fuquana, тада јединог живог Донгбу (Јанековић, 2005: 6).

Ко су Наси?

Нова генерација Наси је као коњске влати, као ротква, могу лако преживети живот.

(Јанековић, 2005: 358)

У Кини, у којој данас живи око 1.3 милијарде становника, 96\% чине Хан Кинези, док 4\% чине припадници 56 националних мањина, од којих чак 25 насељава провинцију Јунан (Yunnan Province), међу њима и националност Наси са око 300 хиљада припадника.

Највећим делом (68\%) Наси живе у древном граду Лиђианг (Lijiang), у северозападном делу Јунан провинције, док је остатак настањен око језера Лугу (Lugu Lake), у југозападном делу провинције Сечуан (Sichuan Province) и на Тибетанској висоравни (Tibetan Plateau) ${ }^{2}$ (Јанековић, 2005: 7).

Сви Наси насељавају тешке терене са хладним планинским подручјима, висоравнима, кањонима, речним долинама, са просечном надморском висином од 2700 м и климом која варира од хладне до суптропске (Јанековић, 2005: 31).

У свом вишевековном ходу, Наси су познати под бројним називима: Моша, Моси, Мосо, Наха, Нари, Лоло, Донгба, „Монголи југа" и др. Тек после комунистичке револуције у Кини 1949. године они себе називају Наси (савр. кинески 纳西族; трад. кинески 納西族; пин-јин: Nàxī zú; ендоним: 1na2khi; са варијантама: Naxi, Nazi, Nazo, Nahsi, Nashi). ${ }^{3}$

2 The Naxi Minority. http://ecotourism.com.cn/discovery-yunnan/ethnic-minority/the-naximinority/ <Приступљено 01. 05. 2017>

3 За време династија Суи (581-618) и Танг (618-907), Наси су били познати као Моша, Моси или Мосо. (Mosha, Moxie, Moso, Mosuo). Насељени око језера Лугу, Моси су данас подгрупа Насија, иако они себе не сматрају Насима. Haха (Nahai, Nahan) или 
На Наси језику, Нахи ( ${ }^{1}$ na- ${ }^{2}$ hi) означава народ Наси што у преводу значи Црни људи, док је Наси ( ${ }^{1}$ na- $\left.{ }^{2} \mathrm{si}\right)$ кованица двеју речи ${ }^{1}$ na (1. црно; 2. тибетанско слово које се често користи уместо црне тачке) n ${ }^{2} \mathbf{s i}$ - (1. човек; 2. људи; 3. мудар човек) што значи ирн човек, ирни људи, али и мудри људи (Јанековић, 2005: 116, 217, 102, 114 ).

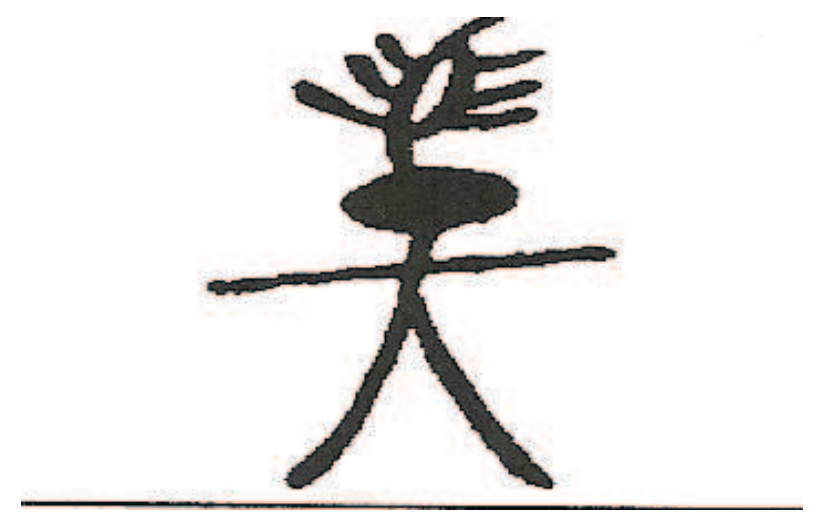

Сл. 1. Народ Наси или Црни људи

Први писани докази о постојању народа Наси датирају од пре 2600 година. Историјски извори кажу да су Наси потомци велике номадске заједнице Ћианг (Qiang), који су у античко доба са северозапада Кине, од обале Жуте реке (Јангце) и провинције Гансу мигрирали ка југу до „Обале белог песка“ “ или данашњег Лиђианга. Наси су се бавили ловом и риболовом, а након миграција и сточарством, пољопривредом и занатством. До данас су задржали многе карактеристике номадских народа. Добродушни су и гостољубиви. Од оруђа које се помиње у најстаријим рукописима користили су летеће камење, конопац, замке, што указује да је лов био основ егзистенције, због чега је приношење жртве богу лова један од значајанијих Донгба ритуала (Јанековић, 2005: 7-8).

Нари (Nachri) насељавају Сечуан и говоре источним дијалектом. Наси, Бурманци и северни Лоло (Lolo) припадају Ји подгрупи тибетанско-бурманске гране, отуда Насије некада називају и Лоло. Назив „Монголи југа“ (Mongolians of South) Hаси су стекли јер насељавају Јунан, најјужнију кинеску провинцију, поетично назване и „Јужно од облака“ (South of Clouds). Уп. Јанековић, 2005: 7; Novačić A. „Ljudi sa druge planete“, НИН, 2001, бр. 2656 (28. нов.). http://www.nin.co.rs/2001-11/28/20845.html $<$ ८риступљено 01. 05. 2017>. Novačić A., op. cit. 


\section{Језик и писмо}

Наси говоре Наси језиком и имају једино живо пиктографско писмо у свету које се на Наси језику зове још и „дрвени“ или „камени“ записи. ${ }^{5}$

Наси језик припада Ји (YI) подгрупи тибетанско-бурманске гране унутар сино-тибетанске језичке групе и подељен је на источни и западни регионални дијалекат. Наха или Нари говоре источним дијалектом, док Наси са седиштем у Лиђиангу говоре западним дијалектом (Јанековић, 2005: 7).

Сликовно писмо народа Наси створиле су Донгбе. На Наси језику, Донгба значи мудрац. Према Донгбама, читава Наси култура назива се Донгба култура. Она вуче корене још из шестог века нове ере. Наси језик се отуда зове још и Донгба језик, а Наси хијероглифи - Донгба писмо. Сачињено од слика, Донгба писмо се чита, рецитује, пева и плеше.

У свом писму, Наси познају четири тона или нагласка, означавајући их бројевима испред сваке речи: 1. кратко-силазни; 2. раван; 3. кратко-узлазни; 4. силазно-узлазни који се појављује само у речима преузетим из кинеског или тибетанског језика. За означавање изговора Јанековић је користио слова српске азбуке ч, ћ, ж и џ, уз неопходан додатак умлаута (ü) из немачког и муклог е (ә) из енглеског језика. Овако добијена транскрипција омогућава изговор сличан оригиналу. Наси пиктограми познају 276 комбинација гласова, док их у говорном језику има много више (Јанековић, 2005: 15).

Поред сликовног писма, Наси су у 7. веку створили и фонетско Геба писмо, међутим оно никада никада није потиснуло симболе. Геба писмо је служило само за превођење мантри и магичних формула.

5 На Наси језику 炸 远母 „запис“, реч „sәr33“ значи „дрво“, а реч „Ічз3“ значи „камен“, отуда „дрвени“ или „камени“ записи. Према интерпретацији Фанг Гуојиа (Fang Guouyu) пиктограм значи „нацртати дрво за дрво и камен за камен“, а према тумачењу Џозефа Рока (Joseph Rock) то су „записи начињени на дрвету и камену“. Према Шеновом (Xu Shen) истраживању, Донгба писмо чини 1076 (47\%) пиктограма, 761 (33\%) идеограм и 437 (19\%) сликовнофонетских карактера, укључујући и позајмљене. Према: What is the Naxi script? http:// sinoglot.com/naxi/what-is-the-naxidongba-script/ <Приступљено 01. 05. 2017>. 
Када пишу о себи, Наси у свом пиктографском писму увек користе црну главу или црну тачку. Термин ${ }^{1}$ na ${ }^{2} \mathbf{s i ~}^{2} \mathbf{v u}{ }^{2}$ dü - Hacu - роб - велики, наводи на претпоставку да су Насије у древна времена вероватно поробили Кинези (Јанековић, 2005: 116). Многи пиктограми у Наси-српском речнику указују на робовски положај, међу њима ${ }^{1} \mathbf{u}$ - слуга; роб и ${ }^{1} \mathbf{đ u ̈ ~ - ~ с л у ш к и њ a , ~ р о б и њ а . ~ П и к т о г р а м и ~ с а ~ з н а ч е њ е м ~}$ слушкиња која доноси воду, роб сточар, дете роб, млади роб, сугеришу да су сви робови имали своја задужења и да су међу робовима била и деца. Пиктограми роб као средство плаћања, роб као жртва боговима, роб који се усудио да пружи отпор и роб који зна да одговори „не“" показују да су у давна времена робови били средство плаћања, да су жртвовани боговима, али и да су услед тешког положаја умели и да пруже отпор и кажу „не“ (Јанековић, 2005: 111-112).

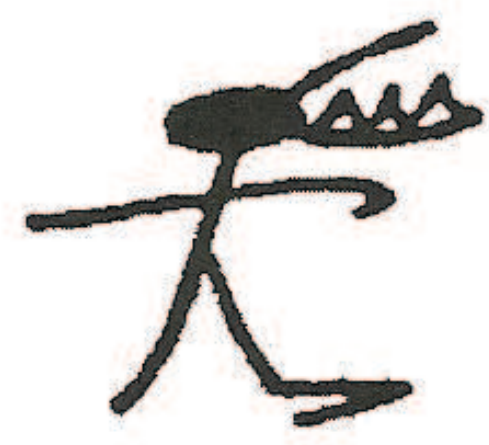

Сл. 2. Роб који се усудио да одговори „не“

\section{Наси пиктограми}

Наси пиктограми очаравају својом лепотом. Њиховим вишеслојним сагледавањем откривамо митолошки, верски и историјски аспект културе Наси, заснованој на симбиози и супротности. Читав низ парова опонената (бело-црно, сребрно-златно, зелено-суво, сунце-месец, светлост-тама, небо-земља, 9-7, 99-77, мушко-женско, јинг-јанг, живот-смрт, бели лептир-црни мрав, богови-демони и др.) показују да јединство супротности чини хармонију. 
Као народ који од давнина познаје астрономију, планетарни систем заузима значајно место у животу Насија. Сазвежђе од 9 звезда сматране су мушким звездама, а сазвежђе од 7 звезда (Велика кола) Наси називају женским звездама. Наси разликују вечерњу и јутарњу звезду, звезде падалице и несрећне звезде које нападају Сунце и Месец. Звезда са које долазе Наси зове се ${ }^{2}$ ku-1 ${ }^{1} \mathbf{d u ̈ ~ ( Ј а н е к о в и ћ , ~ 2 0 0 5 : ~ 1 6 , ~ 1 9 , ~ 2 2 ) . ~}$

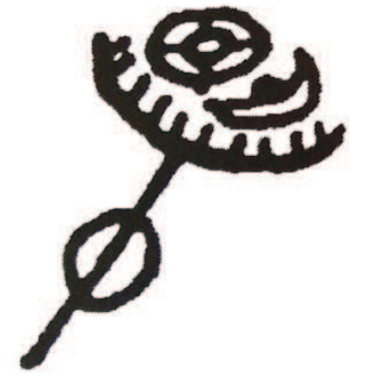

Сл. 3. Несрећне звезде

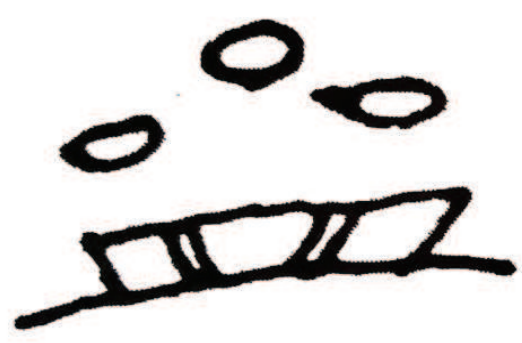

Сл. 4. Звезда са које долазе Наси

У свом писму, Наси имају временске и просторне одреднице. Посебно су занимљиве оне које исказују давно прошло време: „некада давно у древна времена“, „једном, било једном“ или „у почетку, у магловитој прошлости“. Од просторних одредница постоје симболи за стране света, простор „између неба и земље“ и „свугде на свету“ (Јанековић, 2005: 25-26, 29).

Наси имају императивне и сугествне пиктограме: „Иди и донеси воду!“, „Иди и погледај“, „Иди и осветли земљу својом лампом“, „Нека уши чују само пријатне звукове“, „Нека наше уши чују само морољубиве поруке“ и др. У односу на светлост и таму, постоје пиктограми за „оно што раздваја небо од земље и прави ноћ“ и „оно што раздваја небо од земље и прави дан“, али и пиктограми који означавају „граничну линију између црног и белог“, „место сусрета белих и црних вода“" (Јанековић, 2005: 224, 226, 22, 31, 46).

Иако се по правилу бело и црно тумаче као добро и зло, Наси сматрају да у белом увек има мало црног, а у црном мало белог. Супротстављене крајности мире посредници. Ждралови су посредници између неба и земље, смрека између верника и богова, а јутарње и вечерње звезде између сунца и месеца. Као што се поједини еле- 
менти могу спојити, Наси сматрају да постоје и неспојиви елементи: гвожђе и дрво јер гвожђе сече дрво, земља и вода, јер вода плави земљу, вода и ватра, јер вода гаси ватру, ватра и метал, јер ватра топи метал и земља и дрвеће, јер дрвеће живи на земљи (Јанековић, 2005: 231-232).

\section{Веровања}

Наси верују да је живот почео када је топла кап росе пала у језеро и када се из тог златног језера појавило прво људско биће. Оцу народа Наси, као племенском божанству и симболу дуговечности, посвећено је преко двадесет рукописа. Наси га замишљају као старог човека дуге беле браде и високог чела (Јанековић, 2005: 229-230).

Наси верују да потичу са друге планете. Као доказ за то они поносно показују женску народну ношњу на којој је на леђима извезено седам звезда из сазвежђа Велики медвед (Ursa major), док удате жене томе додају сунце и месец (Јанековић, 2005: 164). Новачић их због тога поетично назива „људима са друге планете“. 6 Религијски и древни мотиви на народној ношњи, упућују и на близак однос природе и човека.

Наси верују да су човек, мајмун и медвед истог порекла јер сви имају душе. Према легенди, после велике поплаве, предак Наси је са првом женом усправних очију добио сина за мајмуна. Тибетанци, које Наси сматрају првом и старијом браћом, верују да воде порекло од пара мајмуна и демона (Јанековић, 2005: 103, 118).

Наси верују да све појаве у природи имају душу и да све временске прилике контролишу богови. Када се разболе, они мисле да су сечом дрвећа увредили бога, или да је бог казне украо њихову душу. 3бог тога су одржавани ритуали за призивање душа назад (Јанековић, 2005: 8).

Наси верују да се људи након смрти претварају у демоне.

Наси верују у заглављене душе. Одсуство једне од пет душа проузрокује болест.

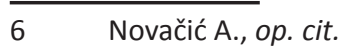




\section{Филологија културе}

Наси верују у два света, стварни и посмртини, сваки има свој цвет (Јанековић, 2005: 71).

Наси верују да куда год да је човек прошао за време живота, проћи ће и након смрти (Јанековић, 2005: 224).

Наси верују да петобојна свилена или платнена трака која се користила за време погребних ритуала симболизује пет елемената од којих је састављен човек (Јанековић, 2005: 231).

\section{Лиђианг}

Лиђианг представља традиционално упориште Наси народа. Према историјским подацима, 1278. године Јуан (Yuan) династија успоставља префектуру у Лиђиангу. У 16. години Хонгву (Hongwu) периода династије Минг, лидер Наси по имену Муди је проглашен наследним шефом префектуре кога је приликом једне посете, император даривао кинеским презименом Мu (дрво). Како знак Mu са рамом означава тешкоће, Лиђианг никада није ограђен зидинама. (Јанековић, 2005: 33)

Стари град у Лиђиангу или на Наси језику „Лепотица која ужива гледајући своје лице у огледалу реке испод Снежне планине Змаја од зеленог жада“" одликује се изузетном лепотом и аутентичношћу, због којих је 1997. године увршћен на Листу светске културне баштине. То је једини град неке етничке мањине који се нашао на УНЕСКОвој листи. ${ }^{7 *}$

$7 \quad$ World Heritage List. http://whc.unesco.org/en/list/

* УНЕСКО (енгл. UNESCO - United Nations Educational, Scientific and Cultural Organization = Организација Уједињених нација за образовање, науку и културу) је специјална организација Уједињених нација основана 1946. године са циљем да допринесе миру и сигурности поспешујући сарадњу међу нацијама кроз образовање, науку и културу. Једна од улога Унеска је да формира листу места светске природне и културне баштине чије очување је од интереса за целокупну светску заједницу. 


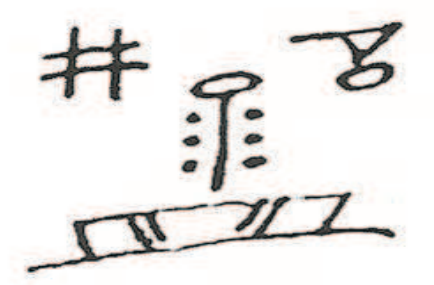

Сл. 5. Древни град у Лиђиангу

Наси верују да се на корак од Лиђианга налази Шангрила, рај на земљи, митско место врхунске хармоније на земљи. ${ }^{8}$ У време династије Танг, Лиђианг је био главна постаја на караванском путну чаја и коња. ${ }^{9}$ Наси оркестри до данас чувају и изводе кинеску класичну музику из тог периода (Јанековић, 2005: 204).

Лиђианг је окружен високим планинама и рекама Минђианг, Јалонгђианг и Ђиншађианг. Град одликују приземне куће уз воду са двориштем препуним цвећа ${ }^{10}$, тргови и бројни мостови над каналима којима јуре брзе и бистре зелене воде односећи са собом све нечистоће (Јанековић, 2005: 7, 34). Мостови су главна места окупљања и трговине. Наси обожавају воду и верују да врховни бог природе живи у пролећним изворима. ${ }^{11}$

Из сваке улице Лиђианга виде се врхови планине који никада нису освојени. Лиђианг се налази у подножју Хималаја или Снежне планине змаја од зеленог жада (Jade Dragon Snow Mountain). Биолози сматрају да чудесна зелена боја снега на планини потиче од алги и

$8 \quad$ Novačić A., op. cit.

9 About Tea-horse Trade Ancient Road. http://www.yunnanadventure.com/index.php/Attraction/show/id/336.html

10 По доласку у Лиђианг, Наси су живели у пећинама, касније су почели да граде куће од бамбуса, дрвета, или зидане. Куће од бамбуса покриване су жутом иловачом, а дрвене куће шиндром притиснуте камењем да је ветар не би одувао. Наси куће су са три стране окружене предњим двориштем, док је на четвртој страни капија. Састоје се из две просторије. У Наси кућама уобичајено је камено огњиште, окружено креветима. Око огњишта су могли спавати само стари људи и младићи, док женама и деци није дозвољено. Огњиште је направљено од три камена, а један угао крај огњишта резервисан је за божанство живота. Преко тог места се не прелази, а приликом пијења чаја, обавезно би се на камење просуло пар капи као понуда прецима и божанству (Јанековић, 2005: 186-187, 172). 
кристала. На падинама Снежне планине, на висини око 4000 м, расте дивљи снежни чај и цветају азалеје током читаве године које тако расцветане падају у језера и плутају док их не поједу рибе, потом медведи из околних околних гора данима силазе да лове пијане рибе (Јанековић, 2005: 37, 181, 11).

Северно од Лиђианга, у манастиру „Врх од жада“ расте „прво дрво испод небеса" краљица свих камелија. Старија од 500 година, почетком сваког пролећа на њој процвета десет хиљада тамноцрвених цветова, док дрво остане у пуном цвату пуних сто дана (Јанековић, 2005: 61).

\section{Сензидоу}

Сензидоу (Shanzidou, 5596м), највиши од 13 врхова Снежне планине, за Наси је света планина. Наси верују да на Снежној планини живи бог планине Сандуо, обучен у ратничу опрему беле боје, јашући на белом коњу, лица белог попут снега и да им помаже у борбама, због чега му пре поласка у рат приносе жртве. Према миту, то је планина на коју су млади љубавници одлазили да изврше самоубиство (Јанековић, 2005: 37).

\section{Однос према браку}

У односу на западну културу, Наси имају неконвенционалан однос према браку. Бракови су били уговарани од стране родитеља како би се сачувао иметак и добило потомство. Склапани су између брата и сестре, Наси припадника и припадника других етничких група. У модерном друштву, моногамни бракови су основни брачни модел. Уговорени бракови били су чест узрок самоубистава међу младима, који нису могли да се помире са чињеницом да брак и љубав не морају бити уско повезани. Отпор према уговореним браковима и немогућност склапања брака из љубави, млади заљубљени парови, или појединци којима није узвраћена љубав, исказивали су одлазећи на свету планину да изврше заједничко самоубиство $-{ }^{1}$ ju- ${ }^{2} \mathbf{v u}$. У ствар- 
ности, они би се тамо смрзли. Због овог социјалног феномена у Наси народу, Лиђианг је познат као град са највише самоубица на свету и зато се назива и Градом мртвих љубавника (Јанековић, 2005: 8, 250).

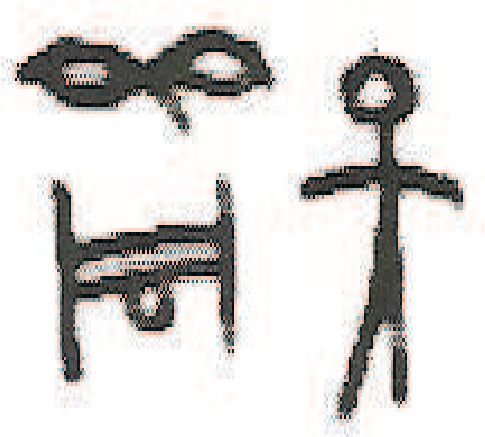

Сл. 6. ${ }^{1} \mathrm{Ju}-{ }^{2} \mathrm{vu}-$ Самоубиство љубавника

Све до демократских реформи Наси су живели у матријархату, када су им Хан Кинези наметнули патријархат. ${ }^{12}$ То је довело до драматичних промена у положају жене која је до тада као глава породице могла да бира мушкарца који јој се свиди. У време матријархата, у случају трудноће, деца би остајала са мајком. Данас, деца наслеђују очево презиме, док Наси жена нема презиме. У Наси друштву, жене су мајке, домаћице и главна радна снага. Стерилна жена се сматра безвредном (Јанековић, 2005: 250, 141).

Филозофија народа Наси

\section{Људи Наси на земљи} ако не живе у људском друштву нестаће...

(Јанековић, 2005: 335-336)

Готово бајковито звучи податак да се у многољудној Кини ова етничка мањина изборила за опстанак и да упркос бројним ратовима

12 у Наси језику још увек постоје трагови матријархата. Ако се уз именицу дода ознака за жену појачава се значење и супротно, ако се уз именицу дода ознака за мушкарца, значење се умањује, нпр. камен + жена значи стена, а камен + мушкарац значи каменчић. 
није асимилована од већинске Хан популације. Постоји мишљење да су се одржали јер су имали кључ за решавање односа на релацији човек - природа - друштво (Јанековић, 2005: 9).

\section{Однос према природи}

Наси сматрају људски род и природу једнаким. Према легенди, људи и бог природе Шу били су браћа по оцу који су се волели и поштовали. Међутим, када је човек постао похлепан и почео да крчи више шуме него што му је потребно и да лови без граница, Шу је поплавио и затровао поља. Посредовањем најстаријег Донгбе, Донгба Шила, помирили су се и направили споразум по коме је Шу одговоран за временске прилике, а људи заузврат морају поштовати природу и њене ресурсе. Зато људи приносе жртве богу Шу како би се природа опоравила од рана и уништавања. Идеја да човек и природа зависе један од другог развио је код Насија снажан осећај за заштиту природе (Јанековић, 2005: 9).

\section{Однос према човеку и друштву}

Као народ који је у прошлости искусио бројне ратове, може се закључити да су Наси опстали јер су схватили да је кључ опстанка међу бројним националностима решавање проблема мирним путем. Ако би се десио сукоб између чланова породице, морала би се одржати церемонија истеривања духова, а у случају сукоба члана породице са неким из спољне средине, одржавала се церемонија „повраћај пошасти“. Виновници сукоба опомињани су да морају одржавати добре међусобне односе и избегавати несугласице. Идеја да су хармонија, склад и скромност највише добро постала је једна од главних вредности у Наси друштву (Јанековић, 2005: 9).

\section{Плаћање дугова}

Идеја о плаћању дугова је важан начин да се одржи равнотежа између човека, природе, друштва, али и међу појединцима, а код 
Наси је развила велику одговорност и свест да се сваки почињени грех мора платити. Када би се разболео члан породице, посвађао са другима или имао проблеме при стварању потомства, сматрало се да духови траже од њих да плате дугове, па су извођени ритуали „плаћања дугова уназад“ (Јанековић, 2005: 9).

Култ предака

Сви моји преци су снажни као лав са Тибета, као слонови и као богови...

(Јанековић, 2005: 335)

Култ предака заузима значајно место код Насија. Градећи живот у компликованом социолошком окружењу и тешким животним околностима, међу високом планинама, хладним рекама и лошом земљом, Наси су своја веровања утемељили на благослову предака и духова, док су неуспехе приписивали демонима. Ради благослова предака, Наси су приносили жртве небесима сваког пролећа, лета и јесени. Кроз овај ритуал развијала се идеја о јединству и значају породице, јер се кроз потомство обнавља дух предака (Јанековић, 2005: $224,10,8)$.

\section{Донгба религија \\ Што Донгба каже истина је записана у стенама као књига постања.}

(Јанековић, 2005: 355)

Примитивна Донгба религија била је популарна међу Насима до средине 20. века. Назив је добила по свештеницима или Донгбама, главним чуварима и преносиоцима традиције, културе, језика и писма народа Наси. Донгбе су своје религиозне сутре ${ }^{13}$ писали сликовним писмом на ручно прављеном папиру. Као учени људи, Донгбе су умели да читају, пишу и рецитују. Познавали су верске каноне,

13 Сутра или поглавље је слика од неколико хијероглифа. 
књижевност, астрономију, географију, рачунање времена, вештине плеса, сликарства, вајарства и ткања. У Наси сликовном писму, Донгба је представљен у облику боце, како седи на лотосу обмотан змијом (Јанековић, 2005: 5, 234).

Наси религија је мешавина политеизма, анимизма и тотемизма. Развијала се под утицајем шаманизма, ламаизма, будизма, таоизма и хришћанства. Наси верују у натприродна божанства и њихову владавину светом. Обожавали су и славили тотеме, претке, природу, богове, шамане... (Јанековић, 2005: 263).

Донгбе или „мудраци", велики учитељи, доктори, чаробњаци, шамани, уметници, врачи, жреци, изводили су ритуале како би излечили болесне, спречили пошасти и заразе, изгонили зле духове, повратили душе умрлих љубавника из пакла, измолили срећу, здравље, љубав, мудрост и дуговечност или предсказали будућност, приносећи жртве боговима неба, воде, ветра. Музика, плес и певање религиозних сутри представљају саставни део ритуала (Јанековић, 2005: 263).

Донгбе су ритуале изводиле у природи, далеко од села, међу камењем и дрвећем, обучени у посебну одору, са капом на глави. Управо ти обреди, којих има преко стотину, и у којима је коришћено преко хиљаду разних рукописа, најважнији су део Донгба културе. Старе Донгбе били су посредници између неба и земље, света живих и света мртвих, богова и демона, човека, природе и друштва. У свакодневном животу, Донгбе су обрађивали земљу и чували коње (Јанековић, 2005: 263).

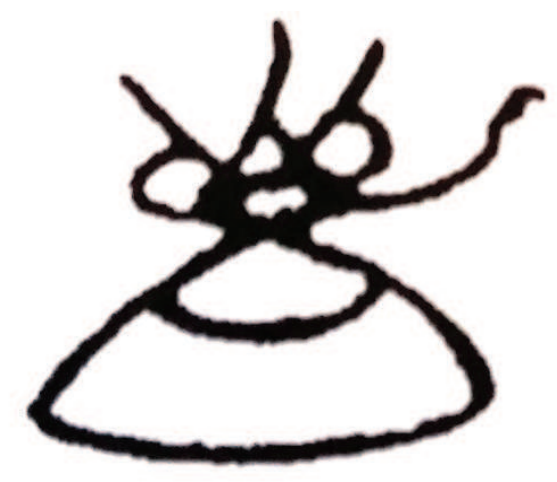

Сл. 7. Донгба са тророгом капом 


\section{Донгба рукописи}

Са циљем да своје знање и искуство пренесу будућим нараштајима, Донгбе су створили пиктографско писмо, које данас на читавом свету уме да чита још само неколицина људи. Донгбе су своја знања и вештине преносили с колена на колено, искључиво на мушког потомка, обучавајући га од најранијег детињства да чита, пише и изводи ритуале. До краја 19. века било је стотину Донгби, почетком 21. само четворица, а недавно је умро и Yang Fuquan, последњи међу њима (Јанековић, 2005: 262, 5).

Са око 2.000 знакова, Донгбе су забележили свој поглед на свет кроз легенде, приче, народне песме, пословице, плес, народне изреке, описали своје страхове и наде али и свакодневни живот народа Наси и њихов однос са другим народима (Јанековић, 2005: 262).

Донгба древни рукописи умножавани су преписивањем. Сваки Донгба би за живота преписивао бар 50 рукописа, што је Донгба античке списе учинило бројнијим. Рукописи су писани на ручно рађеном папиру и повезивани у књиге (Јанековић, 2005: 10).

Насловне странице свих Донгба рукописа су сличне. На средини странице су насликане гране бора које се уобичајено користе у ритуалима, лутка на корицима означава да се ради о ритуалу у којем се користе лутке, симбол Донгба мудраца са тророгом капом указује да се ради о светој књизи, док траке имају декоративну улогу. Иако су Наси симболи мнемотехничког карактера, тј. читају се и памте по принципу асоцијација, некада их је потребно допунити алегоријским фразама. Будући да већина пиктограма има вишеструко значење и изговор, њихово тумачење захтева познавање традиције, локалних обичаја и услова живота (Јанековић, 2005: 262).

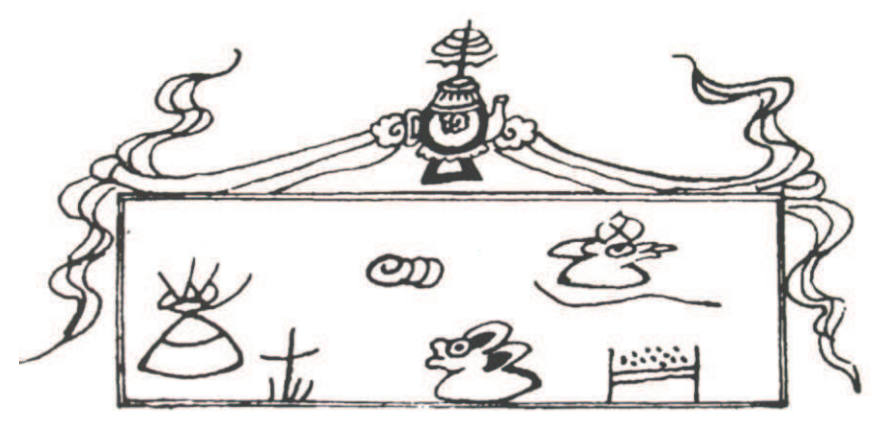

Сл. 8. Насловна страна свих Донгба рукописа 
Нимало случајно, Јанековић је са Донгба пиктограма превео на српски језик три древне приче из богате колекције Донгба рукописа које на најбољи начин осликавају културу народа Наси: „Порекло људи“, „Љубавна прича“ и „Рат белог и црног“. Читајући ове приче, упознајемо основне религиозне идеје, брачне везе и историјски развој народа Наси (Јанековић, 2005: 5).

Порекло људи (Čong Ban) је прича о пореклу народа Наси и његовој вишевековној борби за опстанак. Пратећи причу о три Ли Енова сина из брака са ћерком бога неба, сазнајемо куда су отишли Наси и како су се поделили у групе.

Једни су отишли на Тибет, живели су у белом шатору, гајили тибетанске краве и зелено поврће, правили лутке од пшенице и читали тибетанске књиге. Други су отишли у долину, живели су у великим кућама, гајили биволе и хранили слонове, садили пиринач и црвену пшеницу. Бавили су се уметношћу и предавали религији. Трећи су Наси. Живели су између њих и уживали у слободи. Имали су пуно здраве деце. Веровали су у претке и служили церемоније боговима.

Љубавна прича (Lu Ban Lu Rau) је трагична повест о младим паровима који се опиру уговореном браку и умиру због љубави. По правилу, свако ко побегне од брака мора умрети. Прича је прожета младалачком нестрпљивошћу и ентузијазмом. Млади су одузимали себи живот на разне начине: бацањем са стене или у реку са каменом у наручју или вешањем о дрво, верујући да ће им се након смрти душе спојити са вољенима.

Рат белог и црног (Dong Ai Šu Ai) је митска прича о сукобу два племена око обрадивог земљишта и борби народа Наси да опстане у суровом окружењу. Узрок сукоба између Белог Донг и Црног Су племена је божје дрво које је расло у белом језеру племена Донг. Када је Су пожелео бело, Донг га убија, потом и сам бива убијен из освете. Прича се завршава приношењем жртве да би се окајали греси, како би поколења Донг била срећна, здрава и дуговечна.

Сва три рукописа, у пословички сублимираној форми, обилују мудростима и саветима, утемељеним на искуству: 
Не буди зао.

Не ради ствари које раде вешци.

Не трчи за усамљеним коњем.

Не ори криве бразде.

Не носи копље усправно,

ни сабљу попречно.

(Јанековић, 2005: 313)

Особа која уради добре ствари никада неће бити заборављена Добар човек може дуго живети копита тркаћих коња ће увек бити јака.

(Јанековић, 2005: 323)

Ако господар није окрутан роб неће бежати.

(Јанековић, 2005: 333)

Не буди храна рибама док пецаш.

(Јанековић, 2005: 341)

Када неко умре, живот се претвори у смрт.

Одгајати синове значи имати подршку у старости.

Cадите жито и нећете бити гладни.

(Јанековић, 2005: 354)

Радити и бити богат немогуће је на силу.

(Јанековић, 2005: 355)

\section{Смрт мајке Југовића}

Паралелним преводом српске поеме „Смрт мајке Југовића“ на кинески, енглески, Донгба хијероглифе и српски језик, Јанековић је Наси-српски речник учинио јединственим у свету. Потресна балада о трагедији проузрокованој ратом показује да бол мајке као 
универзална тема човечанства надилази све језичке баријере, верске и културне различитости. Бол мајке за изгубљеним мужем и децом једнак је на свим језицима света.

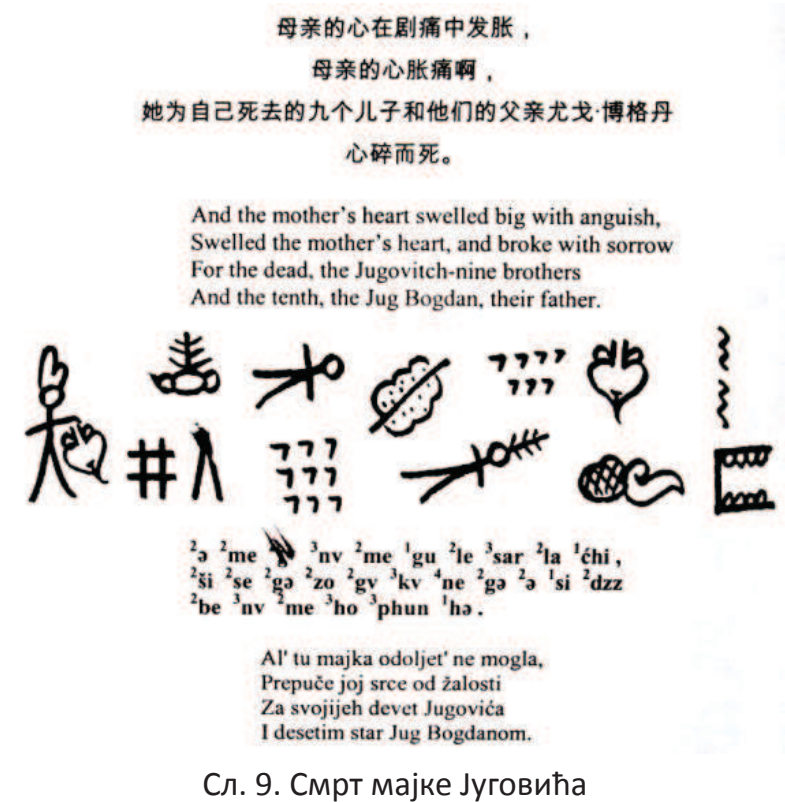

На примеру српске баладе, Јанековић је на симболичан начин показао трагедију свих мајки и жена у рату. Апелујући на мир, комуникацију и разумевање, Јанековић је на најлепши начин повезао културу далеког истока са културом европског југоистока.

\section{Закључак}

Тумачењем пиктограма Наси-српског речника Драгана Јанековића, заокружена је прича о једном изузетно занимљивом и аутентичном народу, који упркос малобројности и суровом окружењу опстаје већ хиљадама година. Прича о етничкој мањини Наси прича је о њиховом језику и писму, религији и филозофији, обичајима и традицији као основним постулатима културе и националног идентитета једног народа. 
Наси или Донгба култура нашла се 2003. године на листи светске културне баштине. Захваљујући Институту Донгба културе са седиштем у Лиђиангу, до данас је сачувано око 20.000 античких Донгба рукописа, који се осим у Кини, чувају у многим библиотекама широм света: у Америци, Немачкој, Аустрији, Британији, Француској, Јапану, а три рукописа су захваљујући Јанековићу доспела и у Народну библиотеку Србије.

Са комерцијализацијом ове древне културе која се гаси, на примеру Наси народа можемо сагледати колико је важно прикупљање језичке грађе на терену. Да Наси пиктограми нису сачувани у речницима, пред нашим очима би нестала једна надасве аутентична и уникатна култура. Да Јанековић није превео Наси пиктограме на српски језик, нико после њега то не би учинио. Забележити језик и писмо који нестају, значи сачувати један народ и његову културу од заборава.

\section{Извори и литература}

About Tea-horse Trade Ancient Road. http://www.yunnanadventure.com/index.php/Attraction/show/id/336.html

Janeković, Dragan. Na-Si srpski rečnik. Narodna biblioteka Srbije, Beograd, 2005.

The Naxi Minority. http://ecotourism.com.cn/discovery-yunnan/ethnic-minority/thenaxi-minority/

Novačić, Aleksandar. „Ljudi sa druge planete“, НИН, 2001, бр. 2656 (28. нов.). http:// www.nin.co.rs/2001-11/28/20845.html

What is the Naxi script? http://sinoglot.com/naxi/what-is-the-naxidongba-script/6. World

Heritage List. http://whc.unesco.org/en/list/ - 
Nataša Jovanović

National Library of Serbia

\section{THE CULTURE OF THE NAXI PEOPLE THROUGH THE PRISM OF THE NA-XI SERBIAN DICTIONARY BY DRAGAN JANEKOVIĆ}

\section{Summary}

The Naxi people (also known as Nakhi, Nari, Mosha, Mosuo, Lolo, Dongba, „the Mongolians of the south") are one of the 56 ethnic minorities in China. There are about 300,000 of them and most reside in the ancient city of Lijiang, in the Yunnan province.

The philosophy of the Naxi rests upon the Dongba religion, named after shamans and sages, the so-called Dogbas, the main carries and keepers of traditions, culture and the script. The old Dongbas wroth their sutras in a pictographic script that only a few people in the world are able to read today.

Drawn by the beauty of the Dongba culture, wich in 2003, was accepted as a written world heritage, the Serbian diplomat Dragan Janeković in 2005 published the $\mathrm{Na}$-xi Serbian dictionary with 1803 pictograms about language, culture, customs, beliefs, traditions and the everyday life of the Naxi people.

Apart from the pictograms, with the meanings and pronunciation adapted to Serbian phonetics, the Na-xi Serbian dictinary also contains reading instructions for the Dongba script, the translations of three ancient Dongba manuscripts into Serbian and the Serbian poem "The Death of the Mother Jugović" rendered in verse into Dongba hieroglyphics.

By interpreting the magical pictograms of the Na-xi Serbian dictionary, from individual pictures we created a magnificent mosaic of this immensely interesting and authentic ancient culture.

Key words: Na-xi Serbian dictionary, Dragan Janeković, Naxi, Dongba culture, ethnic minority, China, Lijiang, language, pictoraphic script, hieroglyphics, The Death of the Mother Jugović 